\title{
Factors Influencing Farmers' Participation in Water Management: A Community Development Perspective
}

\author{
Muhammad Javed Sheikh ${ }^{1,2^{*}}$, Ma'rof B. Redzuan ${ }^{1}$, Asnarulkhadi Abu Samah ${ }^{1}$, \\ Nobaya Ahmad ${ }^{1}$ \\ ${ }^{1}$ (Department of Social and Development Sciences, Faculty of Human Ecology, University Putra Malaysia) \\ ${ }^{2}$ (Department of Rural Sociology, Faculty of Agricultural Social Sciences, Sindh Agriculture University, \\ Tandojam, Pakistan)
}

\begin{abstract}
Participation is believed to a systematic involvement of the significant number of people, in diverse activities to manage their own problems, carrying the concept of togetherness, which enhance the advantages. It always oscillates and depends on the background in which it occurs. Farmers' participation is critical to improve on-farm water management and crop productivity. The study was conducted to identify the factors involved in the fluctuation of participation. This paper reports the results, in which, farmer participation through planning, implementation, monitoring and evaluation of water-user associations were measured, and it was linked to various socioeconomic, demographic, and farm and irrigation characteristics. Multiple linear regression analysis reveals that the participation was positively influenced by age, education, residential locality, house type, lack of on-farm facilities, underground water use for irrigation purpose and location of watercourses on the canal network. However, residential locality and on-farm facilities have significantly negative relationships with the dependent variable in Sindh province of Pakistan.
\end{abstract}

Keywords: Bottom-up approach, community development, participation, socio-economic status, water management.

\section{Introduction}

The communal acceptance of the language of participation across a variety of institutions, from government to non-government to the international donor agencies, raises queries "what in the approved manner?" this extensively slogan has come to mean. Surely, it has always been defined, and depends on the background in which it occurs. The common understanding about "participation" is diverse among different disciplines. Agricultural economists yield it as of farmers getting benefits, while political scientists focus on votes and decision making [1]. The term "Community Participation" refers to a variety of sponsored actions intended to allow poor citizen to influence in decision-making [2]. Participation is simply invited the people to get involved in development processes [3]. Community participation is usually driven by local communities. It is a course of action with many ladders and levels of the development process [4]. Participatory practices involve community members in a process of empowered decision-making and policy implementation [5]. It is a route of social progress in which people meet their collective needs [6]. Participation is an active course of action by which a beneficiary or stakeholder influences the direction and implementation of a project with a vision to enhance pleasure [7]. Cohen \& Manion [8] consider participation as the systematic involvement of a significant number of persons on situation of actions which indeed brings community development.

Community development is a continuous process, aimed at getting better or to bring about pleasant changes through collective action when they prepared themselves to participate in community activities [9]. Abbott [10] simplifies that community development is in fact a particular shape of community participation. Shannon and Walker [11] are of the same opinion that high level of vibrant public involvement is vital to attain community development. However, lack of participation is one characteristic of poverty and social segregation [12]. Community participation facilitates to develop dexterities to gain knowledge to apply collective exertion to outline the outcomes that leads to have power over their lives.

The benefits of community participation are broadly being debated in depth by the different scholars and researchers in community development perspectives. Participatory process gradually steps forward toward the quality of life in the community environment [13]. Uphoff [14] indicated that participation assures equality of access to facilities, while Nikkhah \& Mar'of [15] argued that it upgrades individually and bring empowerment to the community as well. Participatory strategic planning increases local development and sustainable activities in a community [16]. Participation enhances 'sense of ownership' among the members of a community [17]. Consumer-run organizations can lead to positive individual outcomes [18]. It may reduce social isolation and enhance self-efficacy [19]; [20] , and bring sustainability [21]. In short, countries would be 
greatly benefited using a community participation course of action in developmental projects [22], while said to be at the center stage in global development [23]. The above all, the benefits of public participation are beyond the economic value [24].

Participation by local people in development process allows the community to have control over the resources, boost involvement and decision making and develop their common comfort. In order to achieve the benefits, the different interests and aspirations of groups can come together towards formulating common goals or finding solutions in the particular context [25]. People's participation in the context of community development is viewed as a process by which persons are involved in commencing, come to a decision, sketching, put into operation and managing the group and its activities. Participation generates the understanding about the situation, help to get their collective needs and overcome their common problems [6]. Ahmadu, et al. [26] strongly recommended the active participation of community members to achieve sustainable rural development. Participation refers to improved stakeholder sharing in resource use decisionmaking in participatory irrigation management, ultimately, helpful to reduce the poverty and income inequality [27].

Reforms in the water management sector by forming Water Users Associations gradually replace traditional forms of collective management in China that leads to sufficient water saving during the unusual reduction in water [28]. In addition, rural communities can easily avoid the problems related to irrigation through cooperation and active participation and achieve self-reliance [29]. Enhanced community participation has the ability to improve overall water management, including conflict resolutions [30]. The majority of farmers realized that their participation in a watershed group made them aware and understands the issues related to watershed, at the same time they rated their groups advantaged than government guided groups in tackling the issues of conflict [31].

It was reviewed that some of the socioeconomic determinants have strong relationships with participation to place it dynamic. In a study, where the farmers were involved in cleaning of irrigation channels, concluded that the participation level was associated with plot size while the farmers of larger plots were particularly active in water management [32]. Participation positively communicates to intra-personal empowerment across earnings levels, but optimistically related to interactional empowerment only for lowincome individuals [33]. In Nepal, the participation of farmers is influenced by the education level and amount of trainings, while farm size and gross farm income are dominant economic variables influencing participation [34]. On the other hand Saidu, et al. [35] conducted a study in Kano state of Nigeria and divulged that education add negatively to the participation in decision making process as majority of the educated people look for better job opportunities rather to involve in agricultural activities. However, Oladele [36] claimed that age and education level play a vital role in participation. Arun, et al. [37] reported that the participation increases as farm-size increases. Shamiyulla \& Ramu [38] argued that farmers' literacy level, living standard and economic factors also contribute to the success of Participatory Irrigation Management (PIM). Awortwi [39] conducted a study in Africa and Latin America and concluded that income levels and housing categories have positive relationships with factor influencing community participation and supervision. Levels of participation in social and civic community life are significantly influenced by individual socioeconomic status and other demographic characteristics [20].

\section{Methodology}

A participatory process approach might advocate for the public to be involved 'at all stages in the processes. But greater clarity is needed to discern what is contained within the process. Community participation has become popular in development discourse and practice, much involvement of people in decision making, implementation and evaluation of water management practices is expected to increase efficiency and equity in water projects- [40]. For measuring the level of participation of farmers in different stages of water management activities, People's Participation Index (PPI) must be used. An ample list of activities should be recognized before attempting the participation process, casing all the steps, which could be included planning, implementation, maintenance and monitoring \& evaluation [41]; [42]. As far as this study is concerned, the segments of participation included a) involvement in decision making or planning, b) contribution in implementing, c) monitoring and evaluation. However, the study was focused to identify the factors (demographic and socioeconomic condition), contributing in a participatory process.

A cross-sectional study [43] was conducted in Sindh province of Pakistan using multi-stage cluster sampling method. In the first stage 8 canals out of fourteen were randomly selected. In the next step, one distributory/minor from each canal was randomly selected. Followed by, 6 watercourses from each distributory/minor were considered with the segregation of 2 watercourses each from head, middle and tail. At the same time, equal representation of watercourses from left and right side was assured. Finally, 48 watercourses were selected for data collection. Sample sizes of 500 respondents were considered to study at $95 \%$ confidence level and \pm 4.38 confidence interval [44]. For the purpose, 500 respondents were approached to 
dig up information. Out of them, 457 (91.4\%) respondents agreed upon to share their personal and internal information. Self-administered pre-determined questionnaire was developed keeping in mind the objectives of the study. Answers of the questions collected using 6 points (Strongly Agree to Strongly Disagree) Likert scale, open-ended numeric and categorized (yes/no) options.

The validity of the questionnaire was established by the $\mathrm{PhD}$ supervisory committee, previous literature and theory granted for. The reliability of the instrument/scale was measured during data analysis, by applying the Cronbach's Alpha to the variables in putting the initially 50 questionnaire into the SPSS-20. The reliability test was applied to the variables and found the results as follows; Socioeconomic Status (28 items) was standing at .769, and Participation (Planning-16 items) .934, (Implementation-7 items) .731, and (Monitoring and Evaluation-8 items) .863 .

After feeding 457 questionnaires and prior to proposed data analysis (Multiple Linear Regression), normality test was applied to know the distribution of data. Table1 elaborates the normality test of participation elements used in this study. The "Z" score of participation received (Planning 1.85, Implementation 1.77 and Monitoring and Evaluation 0.34).

Table1- Normality Test of Participation Elements

\begin{tabular}{lcccc}
\hline Participation & M & Md & Kurt & Z Score \\
\hline Planning & 60.35 & 60.00 & .422 & 1.85 \\
Implementation & 39.88 & 40.12 & .404 & 1.77 \\
M \& E & 33.63 & 35.00 & .079 & 0.34 \\
\hline
\end{tabular}

\section{Results And Discussion}

A multiple linear regression analysis was directed using "enter" method to evaluate the influence of socioeconomic status of farmers on participation in water management activities at watercourse level. Preliminary analysis was conducted to ensure no violation of the assumptions of normality, linearity, multicollinerity and homocedascity. The results revealed in Table 2 and the regression equation predicting participation is: ParT_M =3.118 + (.367) House type + (-.449) Residential Locality + (-.339) Facilities at farm + (.180) Age $+(.081)$ Education $+(.077)$ Underground water use $+(.096)$ watercourse position.

Approximately $19 \%$ of total variance in participation was accounted by age, education, residential locality, house type, farm facilities, use of underground water and watercourse position of minor, F (7, $449)=14.927, p<.05$. The correlation between house type $(\beta=.242, p<.05)$, residential locality $(\beta=-.240, p<.05)$, farm facilities $(\beta=-.226, p<.05)$, age $(\beta=.173, p<.05)$, education $(\beta=.129, p<.05)$, use of underground water $(\beta=.111, \mathrm{p}<.05)$, watercourse position $(\beta=.093, \mathrm{p}<.05)$, and participation was statistically significant.

More comprehensively, the participation of farmers in water management activities was influenced by age, education, residential locality, house type, use of underground water, facilities at the farm and the watercourse position of the minor. Furthermore, house type was found the most dominant indicator, followed by residential locality, facilities at the farm, age, education, underground water use and watercourse position of the minor in the studied areas of Sindh province of Pakistan. However, residential locality and facilities at the farm level have shown a negative relationship with the dependent variable.

Table2- Factors Affecting in Participation

\begin{tabular}{|c|c|c|c|c|c|}
\hline \multirow[b]{2}{*}{ Model } & \multicolumn{2}{|c|}{ Un-standardized Coefficient } & \multicolumn{2}{|c|}{ Standardized Coeff: } & \multirow[b]{2}{*}{ Sig. } \\
\hline & $\mathrm{B}$ & S.E & Beta & & \\
\hline (Constant) & 3.11 & .287 & & 10.86 & .000 \\
\hline House type & .367 & .072 & .242 & 5.08 & .000 \\
\hline Locality & -.449 & .087 & -.240 & -5.19 & .000 \\
\hline Facilities & -.339 & .068 & -.226 & -5.00 & .000 \\
\hline Age & .180 & .046 & .173 & 3.93 & .000 \\
\hline Education & .081 & .029 & .129 & 2.77 & .006 \\
\hline Underground water & .077 & .030 & .111 & 2.54 & .011 \\
\hline Watercourse position & .096 & .046 & .093 & 2.09 & .037 \\
\hline
\end{tabular}

Likewise, some of the researchers shared same results, indicated contributing factors on participation. It was indicated that participation was influenced by income levels [33]; [37]; [39]; [32]; [38]; [34]; [45]. However, the study did not gather the information of income of the farmers, as respondents were reluctant to share their earnings. Yet, the researcher was guided through the socioeconomic indicators and it was revealed out that among the selected indicators, some socioeconomic variables like, education, house type, residential locality and facilities (electricity, water supply and landline telephone) played a significant role or put the 
influence on participation levels. In addition, education level [33]; [38], housing categories [39]; [45], living standard [38], infrastructure development [45] and location of land on the canal network [46] was also reported in previous studies as the significant variables on participation.

However, residential zone and facilities at farm have a negative relationship with the dependent variable. Further elaboration shows that the farmers, those were habituated away from their farms (cities) the less they involve in participatory processes. Likewise, farmers have less the facilities at farm, more they participate in collective water management activities.

On the other hand, the position of watercourse on the canal network divulged the positive relation to participation. Farmers those occupy their land in the tail of canal network likely to participate more in collective activities regarding to water management. This is why the farmers of tail/remote areas feel insecurity and face scarcity of water most of the times. Therefore, they do participate more in collective activities mainly to get their due amount of water. In addition, less or no usage of underground water for irrigation purpose leads to more participation. The phenomenon indicates that those farmers likely to remain an emphasis onto the canal irrigation system which ultimately increases the chances of participation.

\section{Conclusion}

It was concluded that some of the demographic and socioeconomic indicators have strong relationships in flux of participatory processes of water management. For the information and knowledge to layman, it is summarized that relatively older farmer, having a higher educational level, inhabited in a bungalow on his farm at the end of the canal network system, but lacking on-farm facilities (electricity, tap water and landline telephone) may participate more in the water management activities. However, the availability of surface/canal irrigation water must be ensured.

\section{References}

[1] J. Cohen and N. Uphoff, Rural Development Participation: Concepts and Measures for Project Design, Implementation and Evaluatioon (Ithaka: Cornel University, 1977).

[2] P. K. Eisinger, Citizen Participation: Effecting Community Change, The Journal of Politics, 34(1), 1972, 284-285.

[3] R. Eversole, Remaking participation: Challenges for community development practices, Community Development Journal, 47(1), $2012,29-41$.

[4] R.-I. Emilio, C. G. Michael and O. M.-B. Miguel, Barriers and triggers to community participation accross different stages of conservation management, Environmental Conservation, 37(3), 2010, 239-249.

[5] A. L. Ruano, K. Dahlblom, A.-K. Hurtig and S. S. Miguel, 'If no one else stands up, you have to': a story of community participation and water in rural Guatemala., Global Health Action, 4, 2011, 1-10.

[6] A. S. Asnarulkhadi and A. Fariborz, People's Participation in Community Development: A Case Study in a Planned Village Settlement in Malaysia, World Rural Observations, 1(2), 2009, 45-54.

[7] S. Paul, Community Participation in Development Projects: the World Bank Experience (The World Bank, Washington, D C, 1987).

[8] L. Cohen and L. Manion, Research Methods in Education (London: Croom Helm, 1980).

[9] R. M. Sail and A.-S. Asnarulkhadi, Community Development through Community Capacity Building: A Social Science Perspective, Journal of American Science, 6(2), 2010, 68-76.

[10] J. Abbott, Community participation and its relationship to Community Development, Community Development Journal,30(2), $1995,158-168$.

[11] P. Shannon and P. Walker, Community development and control in a state-local partnership in Aotearoa New Zealand, Community Development Journal,41(4), 2006, 506-520.

[12] L. Platt, Social Participation: How does it vary with illness, caring and ethnic group? (Queen's Printer, Scotland, 2006).

[13] A. S. Asnarulkhadi, Participation and Quality of Life: A Study on the People's Empowerment in a Malay Village Community, Pertanika Journal of Social Sciences \& Humanities, 14(1), 2006, 11-25.

[14] N. Uphoff, Improving International Irrigation with Farmer Participation: Getting the Process Right (Boulder, Colo.: Westview Press, 1986).

[15] H. A. Nikkhah and R. Mar'of, Participation as a medium of empowerment in community development, European Journal of Social Sciences, 11(1), 2009, 170-176.

[16] R. Blair, Public Participation and Community Development: The Role of Strategic Planning, Public Administration Quarterly, 28(1/2), 2004, 102-147.

[17] J. M. Sara and D. Jennifer, Does User Participation Lead to Sense of Ownership for Rural Water Systems? Evidence from Kenya, In World Development,40(8), 2012, 1569-1576.

[18] L. D. Brown, Making it sane: The participation benefits of consumer-run organizations (ProQuest, Wichita State University, 2005).

[19] S. Abbott, Social capital and health: The role of participation, Social Theory \& Health,8(1), 2010, 51-65.

[20] F. E. Bauma, A. B. Robert, C. M. Carolyn, J. M. Charlie, M. C. Eva, M. A. Kathy and C. P. Robert, Epidemiology of participation: an Australian community study, Journal of Epidemiol Community Health, 54, 2000, 414-423.

[21] A. S. Asnarulkhadi, A. Nobaya and M. N. Ndaeji, Rural Women Empowerment through Self Help Groups in Nigeria: The Role of Participation and Volunteerism, Life Science Journal,10(4), 2013, 744-754.

[22] M. G. Mathbor, The Importance of Community Participation in Coastal Zone Management: A Bangladesh Perspective, Community Development Journal,32(2), 1997, 124-132.

[23] A. S. Asnarulkhadi, H. H. Hanina and M. N. Ndaeji, Measuring Rural women Empowerment through Participation in Women Self Help Groups in Nigeria - An empirical analysis, Life Science Journal, 9(8), 2013, 136-141.

[24] W. E. Ansari and E. Andersson, Beyond value? Measuring the costs and benefits of public participation, Journal of Integrated Care,19(6), 2011, 45-57. 
[25] N. Lyndon, R. Moorthy, A. C. Er and S. Selvadurai, Native Understanding of Participation and Empowerment in Community Development, Journal of Social Sciences, 7(4), 2011, 643-648.

[26] S. Ahmadu, A. Nobaya and H. H. Hanina, Perspective on Beneficiaries' Experiences of Participation in Community-Based Agriculture and Rural Development Program in Guba, Northern Nigeria, Asian Journal of Agriculture and Rural Development, 2(1), 2012, 39-45.

[27] M. Bhattarai, R. Sakthivadivel and I. Hussain, Irrigation Impacts on Income Inequality and Poverty Alleviation: Policy Issues and Options for Improved Management of Irrigation Systems (International Water Management Institute, Colombo, 2002).

[28] J. Wang, X. Zhigang, H. Jikun and R. Scott, Incentives in Water Management Reform: Assessing the effect on water use, production and poverty in Yellow River Basin, Environment and Development Economics, 10(6), 2005, 769-799.

[29] Y. Nitising, A Model of Environmental Education for Water Resource Management in Rural Communities., European Journal of Social Sciences,31, 2012, 467-471.

[30] L. Jansky and I. U. Juha, Enhancing Participation in Water Resources Management. Conventional Approaches and Information Technology, Environmental Conservation,33(3), 2006, 274-274.

[31] M. E. Dakins, J. D. Long and M. Hart, Collaborative Environmental Decision Making in Oregon Watershed Groups: Perceptions of Effectiveness, Journal of the American Water Resources Association, 41(1), 2005, 171-180.

[32] Y. Nakano and O. Keijiro, Determinants of household contributions to collective irrigation management: The case of the Doho Rice Scheme in Uganda, Environment and Development Economics, 16(5), 2011, 527-551.

[33] P. W. Speer, N. A. Peterson, T. L. Armstead and C. T. Allen, The Influence of Participation, Gender and Organizational Sense of Community on Pshychological Empowerment: The Moderating Effects of Income, American Journal of Community Psychology,51(1-2), 2013, 243-53.

[34] P. S. Ganesh and B. T. Surendra, Farmers' perception of participation and institutional effectiveness in the management of mid-hill watershed in Nepal, Environment and Development Economics,10(5), 2005, 665-687.

[35] M. B. Saidu, A. A. Samah, M. Redzuan and N. Ahmad, Relationship Between Socio-Economic Factors and Participation in Decision Making in Microfinance Scheme Among Rural Farmers in Kano, Nigeria, Life Science Journal,11(4), 2014, 342-347.

[36] O. I. Oladele, Socio economic determinants of use of indigenous fallow system for enhancing soil fertility among farmers in Oyo State of Nigeria, Life Science Journal,9(3), 2012, 2424-2428.

[37] G. Arun, D. R. Singh, S. Kumar and A. Kumar, Canal Irrigation Management through Water Users Associations and its Impact on Efficiency, Equity and Reliability in Water Use in Tamil Nadu, Agricultural Economics Research Review, 25, 2012, 409-419.

[38] N. Shamiyulla and J. Ramu, Participatory Irrigation Management (PIM) in the Context of Future of Irrigation in India, Asian Journal of Development Matters,4(1), 2010, 18-27.

[39] N. Awortwi, "The riddle of community development: Factors influencing participation and management in twenty-nine African and Latin American communities," Community Development Journal, 48(1), 2012, 89-104.

[40] F. Sultana, Community and participation in water resources management: Gendering and naturing development debates from Bangladesh., Transactions of the Institute of British Geographers, 34(3), 2009, 346-363.

[41] B. Mondal and A. Singh, Stakeholder's Participation In Watershed Management: An Institutional Perspective (Hyderabad, India, 2011).

[42] B. S. Zadeh and A. Nobaya, Participation and Community Development, Current Research Journal of Social Sciences, 2(1), 2010, 13-14.

[43] M. J. Sheikh, S. Sheikh, K. A. A and G. M. Khushk, The Effects of DST on Sleep and Electricity Consumption in Pakistan, The Pakistan Journal of Social Issues, 1(1), 2009, 58-65.

[44] R. V. Krejcie and D. W. Morgan, Determining Sample Size For Research Activities, Educational And Psychological Measurement, 30, 1970, 607-610.

[45] M.-D. Ruth, Farmer participation in irrigation, Irrigation and Drainage Systems, 11, 1997, 103-118.

[46] C. K. Madhava and G. Chackacherry, Factors influencing farmer participation in irrigation management, Journal of Tropical Agriculture, 42 (1-2), 2004, 77-79. 